\title{
Heterosis Effect and Outbreeding Analysis of Boer and PE Goat Crosses Based on Birth Weight in F1 and F2
}

\author{
Rosidi Azis $^{(1)}$, Gatot Ciptadi ${ }^{(2)}$, Suyadi ${ }^{(3)}$ \\ ${ }^{(1)}$ Department of Animal Science, Universitas Nahdlatul Ulama Blitar, Indonesia \\ ${ }^{(2)(3)}$ Department of Animal Production, Universtas Brawijaya, Indonesia \\ E-mail: ${ }^{(1)}$ rosialfatih1953@gmail.com
}

Received: 15 April 2020; Revised: 15 Mei 2020; Accepted: 20 Mei 2020

\begin{abstract}
Abstrack
The Boer and PE goat was used as a model in the outbreeding application to look at the genetic mechanism responses. The purpose of this research to analyze the estimation of heterosis effect on the birth weight of the Boer and PE goat crosses. The total data used in this experiment were birth weight (BW) data from F1 (89 tails) and F2 (16 tails), respectively. Data analysis was estimated by calculating the probability of BW using the average formula and standard deviation based on Noor (1996) formula. The results of the data analysis using the formula above, carried out further using "t-test" to know the difference in the birth weight of F1 and F2 with $\alpha 0.05$. The heterosis effect was analyzed based on Harjosubroto (1994) formula. The results of this research that BW of F1 and F2 were $3,91 \pm 0,88 \mathrm{~kg}$ and $3,47 \pm 0,76 \mathrm{~kg}$, respectively. The results were higher than $\mathrm{BW}$ of Boer goat and $\mathrm{PE}$ goat $(3,3 \mathrm{~kg})$. The ration of $\mathrm{BW}$ between $\mathrm{F} 1$ and $\mathrm{F} 2$ was not significant $(\mathrm{P}>0,05)$. Heterosis effect analysis of F1 $(46,67 \%)$ and F2 $(32,17 \%)$ were higher than parental. It would be concluded that the result of birth weight very large released by sex of goat. The average of the male group had higher than the female group. The effect was caused by the Boer goat as male in passing down the transition. The effect of heterosis on goats from the highest crosses in the first generation (46.67\%), and reduced in the second generation (32.17\%). The heterosis effect value could be made as a basis for future selection program.
\end{abstract}

Keywords: Goat; birth weight; outbreeding; crossbreeding; heterosis effect;

\section{Introduction}

The study of factors affecting birth weight in cattle, sheep, and goats is important for value for several reasons (Bharathidhasan et al., 2009, Banerjee and Jana, 2010). Birth weight has several impacts on health status and survival on livestock. The relationship between birth weight and death has long attracted geneticist because death is caused by abnormal birth weight (Bwogi et al., 2017, Omani et al., 2019).

Birth weight is a factor that affects the life span of livestock from birth to adulthood (Woma et al., 2016). The birth weight does not have important economic value, but birth weight can be used as a characteristic for early selection (Azis, 2012, Omani et al., 2019). Selection based on the birth weight of livestock is the first step to do, where the birth weight that is not good needs to be removed from the farm. This is because the nature of birth weight is a trait that can be taken into consideration in the selection program (Banerjee and Jana, 2010, Syakur and Azis, 2020).

Some factors that can affect birth weight are birth type, sex, age of mother, feed and breed (Nurgiartiningsih, 2012, Radhika et al., 2015). The birth weight of tropical goats for sin- 
gle male and female were $1.8-4.9 \mathrm{~kg}$ and 1.6 $4.2 \mathrm{~kg}$, respectively, and the birth weight of twins (two males) were $1.8-4.4 \mathrm{~kg}$ and 1.7 $3.9 \mathrm{~kg}$, respectively (Pralomkarn and Tumwasorn, 2011, Harowi, 2016). In addition, large goat breed has birth weight (male) ranging from $2.7-4.0 \mathrm{~kg}$ (single) and $2.9-3.5 \mathrm{~kg}$ (twins) and female birth weight around $2.5-3.7$ $\mathrm{kg}$ (single) and $2.8-3.0 \mathrm{~kg}$ (twins) (Thepparat et al., 2012, Harowi, 2016). Other factors affecting the birth weight of an older child are greater than the birth of twins or triplets (Radhika et al., 2015). This is due to the food obtained by the fetus from the mother who has more single children compared to twins or the amount of subsequent weight gain and the ability to adapt to the environment (Bharathidhasan et al., 2009, Banerjee and Jana, 2010).

Crossbreeding between Boer goats and PE goats substitutes the desired traits in their offspring and utilizes the superiority of livestock in heterozygote (Azis, 2012, Harowi, 2016, Azis and Kurniawan, 2019). The crossing of Boer goat and PE goat is an attempt to produce new offspring that have the proportion of blood as the neighbor (Harowi, 2016, Azis and Lestariningsih, 2018). Livestock breeding through the crossing application is based on the heterosis effect (Azis, 2012, Al-Saef, 2013, Harowi, 2016, Azis and Lestariningsih, 2018). Heterosis is defined as an increase in the size/ shape (vigor) of a hybrid over its parent's average (Hassen et al., 2012, Azis, 2018). Heterosis effect is the effect of changes in the appearance of crossbreeds progeny average that are consistently different from the appearance of the two parents average (Azis, 2012, 2018). The heterosis effect can be seen based on the similarity of phenotype characteristics of progeny.

Crossbreeding of Boer and PE goats is a common practice developed by farmers in Indonesia and other countries, that these crosses can inherit superior traits possessed by their parents. It is important to study the first generation and second-generation (F1 and F2) as well as analysis of phenotypic similarities, birth weight performance and estimation of the effects of heterosis on birth weight of their crosses

\section{Material and Methods}

This study was used the result of crossing Boer and PE goat, namely the first generation (F1) and the second generation (F2). Ther number of the materials was 89 tails (F1) and 16 tails (F2), respectively. Data collection was obtained based on observations in the field directly on a quantitative trait. Quantitative characteristic is characteristic that can be measured against the performance of F1 and F2 specifically on Birth Weight (BW). Heterosis effect is the result of the measurement of change in the appearance of phenotype characteristics, especially BW of F1 and F2 generation.

Data analysis was estimated by calculating the probability of BW using the average formula and standard deviation based on (Rachman, 2004) formula. The results of the data analysis using the formula above carried out further using the "t-test" to know the difference in the birth weight of F1 and F2 with $\alpha 0.05$.

Heterosis effect (hybrid vigor) analysis was carried out to determine the estimation of hybrid vigor as measured by hybrid vigor coefficient heterosis $(\% \mathrm{H})$ as describe (Warwick et al., 1984). Which was defined to determine the differences between F1 and F2 with their parent.

\section{Results and Discussion \\ Birth Weight of F1 and F2}

Birth weight has important significance for predicting livestock productivity and reproduction. Birth weight correlates with growth rate, adult size and life force of livestock. According (Warwick et al., 1984) that birth weight does not have an important economic value, but birth weight can be used as a criterion for early selec-

Table 1. The Average of birth weight in F1 and F2 (kg)

\begin{tabular}{|l|c|c|c|c|}
\hline \multirow{3}{*}{ Gender } & \multicolumn{2}{|c|}{ F1 (kg) } & \multicolumn{2}{c|}{ F2 (kg) } \\
\cline { 2 - 5 } & $\begin{array}{c}\text { Number } \\
\text { (Tails) }\end{array}$ & $\begin{array}{c}\text { Average } \\
\overline{\boldsymbol{X}}+\text { SD }\end{array}$ & $\begin{array}{c}\text { Number } \\
\text { (Tails) }\end{array}$ & $\begin{array}{c}\text { Average } \\
\overline{\boldsymbol{X}} \\
\pm \text { SD }\end{array}$ \\
\hline Male & 45 & $4,01 \pm 0,80$ & 8 & $3,94 \pm 0,94$ \\
\hline Female & 47 & $3,81 \pm 0,93$ & 8 & $3,06 \pm 0,19$ \\
\hline Average & $\mathbf{9 2}$ & $\mathbf{3 , 9 1} \pm \mathbf{0 , 8 8}$ & $\mathbf{1 6}$ & $\mathbf{3 , 4 7} \pm \mathbf{0 , 7 6}$ \\
\hline
\end{tabular}


tion because there is a relationship with livestock production in the future.

The results of the analysis of the birth weight of F1 and F2 offspring from pure male Boer goat crossing with the parent PE goat obtained average birth weight as shown in (Table $1)$.

The average birth weight of goats from Boer and PE crosses was in the F1 group, it was found that male was $4.01 \pm 0.80 \mathrm{~kg}$ and female was $3.81 \pm 0.93 \mathrm{~kg}$, whereas in group F2 it was found, the male was around $3.94 \pm 0,94 \mathrm{~kg}$ and in females $3.06 \pm 0.19 \mathrm{~kg}$. The results of statistical analysis comparing the average birth weight F1 and F2 show that the average birth weight of F1 and F2 were not significantly different $(\mathrm{P}>0.05)$.

Based on Table 1 showed that male and female birth weight, male birth weight was greater than the female of the goat. The same results reported by (Harowi, 2016), which crosses Boer goats with local Chinese goats produce a greater average birth weight of male goats $(4.25 \pm 0.95 \mathrm{~kg})$ compared to female goat birth weight $(3.74 \pm 0.10 \mathrm{~kg})$. Another study conducted by (Thepparat et al., 2012) who also crossed Boer goats with Chinese local goats, reported that birth weight was significantly different between male and female goats resulting in crossings of $6.43 \pm 1.42 \mathrm{~kg}$ and 3.37 $\pm 0,74 \mathrm{~kg}$. The combination of Boer goat crosses as male inherited greater production traits than local goats.

According to (Bharathidhasan et al., 2009), the difference is due to the speed of prebirth growth of male goats which is faster than female goats. Its based on the assumption that androgen hormones owned by male children will cause more nitrogen retention compared to female children so that will result in greater fetal growth, therefore male fetuses will have greater pre-birth growth so that they have greater birth weight as well compared to female children. Birth weight of goat is influenced not only by litter size, sex of the child but also by season, whereas parity/age of the mother and additional feed have no significant effect (Bharathidhasan et al., 2009, Pralomkarn and Tumwasorn, 2011, Nurgiartiningsih, 2012).

Differences in birth weight are influenced by several genetic factors, gender, feed, and maintenance management (Bharathidhasan et al., 2009, Radhika et al., 2015). In addition, there are two possibilities: firstly, the difference in birth weight is probably due to the high average litter size of the mother of the goat PE which causes the average birth weight of the child per-tail to be low. Secondly, caused by the average weight of a PE goat in Lampung province $(34.5 \mathrm{~kg})$ which is higher than the average weight of a PE goat in East Java (31.7 kg) (Azis, 2012, Harowi, 2016).

Based on the results of research conducted by (Nasich, 2010) said that birth weight was influenced by the place where the livestock were kept or the location and age of the parent, where Malang Regency had an average birth weight of $3.07 \mathrm{~kg}$, while Tulungagung was $2.39 \mathrm{~kg}$. In addition, the age of PE goats used in Tulungagung Regency was on average for more than 3 years, while the parent of PE goats in Malang on average was less than 3 years. Seasonal and maintenance location factors influence the birth weight of children because it is closely related to the availability of forage in the field. Childbirth weight in the rainy season was higher than in the dry season.

The average birth weight of crossbreed goats was generally higher when compared to the average birth weight of both parents. The Boer goat birth weight was assumed to be an average of $3.3 \pm 0.64 \mathrm{~kg}$ (Browning Jr et al., 2011) and the average birth weight of the PE goat was 2.36 $\pm 0.36 \mathrm{~kg}$ (Dakhlan and Suharyati, 2012). The average birth weight of goat resulting from the crossing of Boer goat conducted by (Romjali et al., 2002, Mahmilia and Tarigan, 2004) in Boer goat mated with pea goats have a birth weight of $2.22 \mathrm{~kg}$ and $1.98 \pm 0.43 \mathrm{~kg}$, respectively. The results of research conducted by (Yonghong et al., 2001) who mated Boer goats with Huai and Haimen goats produced birth weight ranging from $2.75 \pm 0.23 \mathrm{~kg}$ and $2.50 \pm 0.47 \mathrm{~kg}$. Sutaman et al (2002) who mated Boer and PE goat with an average birth weight of $4.29 \pm 0.63 \mathrm{~kg}$.

\section{Heterosis effect}

One of the expected of crossbreeding among livestock is heterosis (Thepparat et al., 2012). Heterosis (hybrid vigor) can be divided into two types, namely individual heterosis and maternal heterosis (Harowi, 2016). The type of individual heterosis is used in crossing between two breeds, which was distinguished as differences in appearance between individuals resulting from reciprocal crosses (crossbred) with the average appearance of their parent nations (straightbreed or purebred). The magnitude of the effects of heterosis depends on the level of genetic differences between the original breed. The further 
Table 2. The estimation of heterosis effect of F1 and F2

\begin{tabular}{|l|c|c|c|c|}
\hline \multirow{2}{*}{ Gender } & \multicolumn{2}{|c|}{ F1 } & \multicolumn{2}{c|}{ F2 } \\
\cline { 2 - 5 } & $\begin{array}{c}\text { Number } \\
\text { (Tails) }\end{array}$ & $\begin{array}{c}\text { The percentage } \\
\text { of heterosis } \\
(\% H)\end{array}$ & $\begin{array}{c}\text { Number } \\
\text { (Tails) }\end{array}$ & $\begin{array}{c}\text { The percentage of } \\
\text { heterosis } \\
\text { (\%H) }\end{array}$ \\
\hline Male & 45 & 22,26 & 8 & 19,94 \\
\hline Female & 47 & 24,41 & 8 & 12,23 \\
\hline Average & $\mathbf{9 2}$ & $\mathbf{4 6 , 6 7}$ & $\mathbf{1 6}$ & $\mathbf{3 2 , 1 7}$ \\
\hline
\end{tabular}

differences between the two basic breed, heterosis effect will be even greater. The result of crossing obtain a high individual heterosis effect, then the cross-breeding system can be recommended to be applied (Nurgiartiningsih, 2012, Radhika et al., 2015).

The average birth weight of Boer goats was $3.3 \pm 0.64 \mathrm{~kg}$, and the average birth weight of PE goats was $3.67 \pm 0.36 \mathrm{~kg}$ (Kostaman and Sutama, 2005, Browning Jr et al., 2011). If the two birth weights are added up and divided in half it will produce $3.48 \pm 0.5 \mathrm{~kg}$.

Based on the results of the data in table 2, it shows that the estimation of the effects of heterosis on first-generation birth weight is higher than the second generation. The F1 groups in males and female the average were $22.26 \%$ and $24.41 \%$, respectively. While the F2 groups in males and females were $19.94 \%$ and $12.23 \%$, respectively. The results of the estimation calculation of the heterosis effects in the F1 group obtained an average was $46.67 \%$, while in the F2 group the results of average were $32.17 \%$. The results indicate that the F1 group had $46.67 \%$ of the advantages of its parental, whereas in F2 group had $32.17 \%$ of the advantages of its parental.

Based on the results in table 2, that this study showed that the heterosis effect tends to decrease in the F2 group. Some studies said that the highest individual heterosis was achieved in the first generation and showed a decrease in the second and third generations. The percentage of heterosis value will decrease by half the value of the second and third generation (Nurgiartiningsih, 2012, Thepparat et al., 2012, Radhika et al., 2015). The cause of this heterosis is not yet known with certainty. Heterosis effects are probably caused by the action of non -additive genes, which can cause dominance or over dominance. Gene action plays a major role assuming low recessive alleles in the majority of offspring (Nasich, 2010). On the other hand, the beneficial epistatic interactions as the main reason for the occurrence of phenomena heterosis at the molecular level (Browning Jr et al., 2011, Thepparat et al., 2012).

\section{Conclusion}

Based on the result of this study could be concluded that birth weight had no economic value, but the birth weight had a relationship with growth trait, health status and the basis of selection. The result of birth weight very large released by sex of goat. The average of the male group had higher than the female group. The effect was caused by the Boer goat as male in passing down the transition. The effect of heterosis on goats from the highest crosses in the first generation (46.67\%), and reduced in the second generation $(32.17 \%)$. The value of the heterosis effect could be made as a basis for future selection program.

\section{Suggestion}

The study of birth weight as a basis for early selection in the future requires more complete and more complex research to validate its correlation with the health status of goats (F1 and F2).

\section{References}

Al-Saef, A. (2013). Genetic and phenotypic parameters of body weights in Saudi Aradi goat and their crosses with Syrian Damascus goat. Small ruminant research 112(1-3):35-38.

Azis, R. (2012). Kemiripan Fenotipik Dan Estimasi fek Heterosis Berat Lahir Kambing Hasil Persilanagan Boer Dan Peranakan 
Etawah (Pe) Generasi 1 Dan 2. Universitas Brawijaya.

Azis, R. (2018). Pengujian dosis larutan air garam ( $\mathrm{NaCl} / \mathrm{Natrium}$ Cloride) terhadap daya tetas telur itik pedaging hibrida super Jurnal Ilmu-Ilmu Peternakan 28(2):168-174.

Azis, R. and D. Kurniawan. (2019). Strategi Peningkatan Kemampuan Peternak Itik Melalui Pelatihan Manajemen Pakan Itik Terhadap Kelompok Peternak Itik Hibrida Super di Desa Slorok Kecamatan Doko Kabupaten Blitar. Jurnal Pengabdian dan Pemberdayaan Nusantara (JPPNu) 1(1):25-31.

Azis, R. and L. Lestariningsih. (2018). Pelatihan Managemen Budidaya Itik untuk Meningkatkan Produksitivas Kelompok Ternak di Desa Slorok Kecamatan Doko Kabupaten Blitar. Briliant: Jurnal Riset dan Konseptual 3(4):436442.

Banerjee, S. and D. Jana. (2010). Factors affecting birth weight of Sirohi goat kids reared in hot and humid climate of west Bengal. World Applied Sciences Journal 9(12):1379-1382.

Bharathidhasan, A., R. Narayanan, P. Gopu, A. Subramanian, R. Prabakaran, and R. Rajendran. (2009). Effect of nongenetic factors on birth weight, weaning weight and preweaning gain of Barbari goat. Tamilnadu. J. Vet. Anim. Sci 5 (3):99-103.

Browning Jr, R., M. Leite-Browning, and M. Byars Jr. (2011). Reproductive and health traits among Boer, Kiko, and Spanish meat goat does under humid, subtropical pasture conditions of the southeastern United States. Journal of animal science 89(3):648-660.

Bwogi, J., K. C. Jere, C. Karamagi, D. K. Byarugaba, P. Namuwulya, F. N. Baliraine, U. Desselberger, and M. IturrizaGomara. (2017). Whole genome analysis of selected human and animal rotaviruses identified in Uganda from 2012 to 2014 reveals complex genome reassortment events between human, bovine, caprine and porcine strains. PLoS One 12(6):e0178855.

Dakhlan, A. and S. Suharyati. (2012). Performance of Grade-1 Kids as A Result of Grading-Up Between Local Goat and Boer Goat. in Proc. International Semi- nar on Animal Industry.

Harowi, M. (2016). Perbandingan Koefisien Heterosis antara Kambing Boerawa dan Saburai Jantan pada Bobot Sapih di Kecamatan Sumberejo Kabupaten Tanggamus.

Hassen, H., M. Baum, B. Rischkowsky, and M. Tibbo. (2012). Phenotypic characterization of Ethiopian indigenous goat populations. African Journal of Biotechnology 11(73):13838-13846.

Kostaman, T. and I. Sutama. (2005). Pre-weaning growth of Boer $\mathrm{x}$ Peranakan Etawah goats. Jurnal Ilmu Ternak dan Veteriner 10(2):106-112.

Mahmilia, F. and A. Tarigan. (2004). Karakteristik morfologi dan performans kambing Kacang, kambing Boer dan persilangannya. Pros Lokakarya Nasional Kambing Potong. Bogor:209-212.

Nasich, M. (2010). Analisis fenotip dan genotip kambing hasil persilangan antara pejantan Kambing Boer dengan induk kambing lokal. Fakultas Pertanian UB. Disertasi. Malang.

Nurgiartiningsih, V. A. (2012). Evaluasi genetik pejantan Boer berdasarkan performans hasil persilangannya dengan kambing lokal. TERNAK TROPIKA Journal of Tropical Animal Production 12(1):8288.

Omani, R. N., G. C. Gitao, J. Gachohi, P. K. Gathumbi, B. A. Bwihangane, K. Abbey, and V. J. Chemweno. (2019). Peste Des Petits Ruminants (PPR) in Dromedary Camels and Small Ruminants in Mandera and Wajir Counties of Kenya. Adv Virol 2019:4028720.

Pralomkarn, W. and S. Tumwasorn. (2011). Estimation of additive, non additive gene effects and genetic parameters on preweaning growth traits in goats meat in southern Thailand. Walailak Journal of Science and Technology (WJST) 8(1):41 -50 .

Rachman, N. (2004). Genetika Ternak. Penebar Swadaya, Jakarta.

Radhika, G., K. Raghavan, T. Aravindakshan, and V. Thirupathy. (2015). Genetic diversity and population structure analysis of native and crossbred goat genetic groups of Kerala, India. Small Ruminant Research 131:50-57.

Romjali, E., L. P. Batubara, K. Simanihuruk, and S. Elieser. (2002). Keragaan anak hasil 
persilangan kambing Kacang dengan Boer dan Peranakan Etawah. Pages 113 -115 in Proc. Pros. Seminar Nasional Teknologi Peternakan dan Veteriner. Bogor.

Syakur, A. and R. Azis. (2020). Developing Reading Learning Model to Increase Reading Skill for Animal Husbandry Students in Higher Education. Britain International of Linguistics Arts and Education (BIoLAE) Journal 2(1):484493.

Thepparat, M., M. Duangjinda, S. Tumwasorn, S. Anothaisinthawee, and W. Boonkum. (2012). Random heterosis effects on genetic parameters, estimation of birth weight, and Kleiber ratio in a population admixture of Thailand goats. Livestock science 147(1-3):2732.

Warwick, E. J., J. M. Astuti, and W. Hardjosubroto. (1984). Pemuliaan ternak. Gadjah Mada University Press.

Woma, T. Y., P. S. Ekong, D. G. Bwala, J. O. Ibu, L. Ta'ama, D. Y. Dyek, L. Saleh, D. Shamaki, D. J. Kalla, D. Bailey, H. M. Kazeem, and M. Quan. (2016). Serosurvey of peste des petits ruminants virus in small ruminants from different agro-ecological zones of Nigeria. Onderstepoort J Vet Res 83(1):1035.

Yonghong, H., C. Qinkang, H. Genghua, and Y. Zhangping. (2001). Effect of Boer goat crossbreeding with Haimen goats and Huai goats in Jiangsu province. Pages 192-197 in Proc. Proc. 2001 Int. Conf. Boer Goats, Guizhou, China.

Satisfaction as an Impact of the System Quality, Information Quality, and Top Management Support, upon the Perceived Usefulness of Technology Utilization. Journal of Marketing Development and Competitiveness . 2019, Vol. 13 Issue 1, pp.59-75. 17p.

Pinar; Mehtap; Erzengin. (2012). The Effect of End User Perceptions of Information Technologies on The Information Sharing. Journal of Global Strategic Management, Vol.6 (1), pp.32-41.

Rigopoulos, George.,Dimitrios Askounis. (2007). A TAM Framework to Evaluate User's Perception Toward Online Electronic Payments. Journal of Internet Banking and Commerce, Desember, Vol. 12, No. 3, pp. 1-5.
Rouibah, HI; Hamdy; MZ. Al-Enezi. (2009). Effect of Management Support, Training, and User Involvement on System Usage and Satisfaction in Kuwait. Journal Industrial Management and Data System. 109 (3).338-356.

Seddon PB.; Kiew MY.; Patry, Mchel. (1994). A Partial Test and Development of DeLone and McLean's Model of IS success. Australian Journal of Information Systems, Vol.4, n.1, pp.90-109

Seddon, PB. (1997). A Respecification and Extension of the DeLone and McLean Model of IS Success. Journal of Information Systems Research, Vol.8, pp.240-253. http:// dx.doi.org/10.1287/isre.8.3.240-253

Sinarwati, Ni Kadek dan Kertiasih, Ni Ketut. (2017). Pengembangan Sistem Informasi Akuntansi Berbasis Mobile Bagi UMKM. Laporan Penelitian. LPPM Undiskha, Singaraja

Sinarwati, NK.; Herawati, NT.; Sujana, E. (2019). Peran Sistem Informasi Akuntansi Berbasis Mobile Bagi Peningkatan Kinerja UMKM. Conference: WNCE (Warmadewa Natonal Economic Conference at Denpasar

Venkatesh, V. dan Davis, F.D. (2000). A Theoretical Extension of the Technology Acceptance Model: Four Longitudinal Field Studies. Management Science, Vol. 46 (2), pp. 186-204

Arief Wibowo. (2006). Kajian tentang Perilaku Pengguna Sistem Informasi dengan Pendekatan Technology Acceptance Model (TAM), Universitas Budi Luhur, Jakarta.

Y. Kim; HS Lee. (2014). Quality, Perceived Usefulness, User Satisfaction, and Intention to Use: An mpirical Study of Ubiquitous Personal Robot Service". Asian Social Science, Vol. 10 (11), pp. 1-16 